\title{
Heat pain detection threshold is associated with the area of secondary hyperalgesia following brief thermal sensitization: a study of healthy male volunteers [Corrigendum]
}

\author{
Hansen MS, Wetterslev J, Pipper CB, Asghar MS, Dahl JB. \\ Journal of Pain Research. 2017;10:265-274.
}

On page 267, right column, 2nd paragraph, line 10, the first sentence under "Assessment of secondary hyperalgesia" should read "The area of secondary hyperalgesia was quantified after pinprick stimulation with monofilament (von Frey hair) with a nominal value of 18 (bending force of $490 \mathrm{mN}$ ) in 4 linear paths arranged $90^{\circ}$ around the center of the thermode".

The Journal of Pain Research is an international, peer reviewed, open access, online journal that welcomes laboratory and clinical findings in the fields of pain research and the prevention and management of pain. Original research, reviews, symposium reports, hypothesis formation and commentaries are all considered for publication.

\section{Dovepress}

The manuscript management system is completely online and includes a very quick and fair peer-review system, which is all easy to use. Visit http://www.dovepress.com/testimonials.php to read real quotes from published authors. 